\title{
ASSESSMENT OF 14-3-3 PROTEIN ETA AND ANTI- CYCLIC CITRULLINATED PEPTIDE (ANTI-CCP) IN JUVENILE IDIOPATHIC ARTHRITIS VERSUS ADULT ONSET RHEUMATOID ARTHRITIS
}

\author{
By \\ Mohammed A. Hassan'1, Rasha M. Gouda1, Wagenat E. Alsayed ${ }^{2}$ and \\ Iman A.Kassem ${ }^{3}$ \\ Departments of ${ }^{1}$ Pediatrics, ${ }^{2}$ Internal medicine and ${ }^{3}$ Clinical Pathology \\ Faculty of Medicine (Girls and Boys), Al-Azhar University
}

\begin{abstract}
Background: 14-3-3(eta) protein, is an intracellular chaperone (cellular adapter) protein, which released to the extra cellular space during the early stages of the rheumatoid arthritis (RA), and acts as an inducer of innate immune system. Many inflammatory mediators and pathways that involved in the pathogenesis and progression of RA have been upregulated through 14-3-3 eta protein. So, this marker in addition to existing biomarkers can augment the lab efficacy in the early identification and progression assessment of the RA.
\end{abstract}

Objective: Investigating the existence of anti-CCP antibodies and 14-3-3 protein eta in juvenile idiopathic arthritis (JIA) and RA patients, comparing that with healthy controls and correlated their levels with Disease Activity Score (DAS 28).

Patients and Methods: Serum levels of 14-3-3 eta protein and anti-CCP were measured using enzymelinked immunosorbent assay (ELISA) in 40 patients including 20 JIA cases (group I), 20 RA cases (group II), and 40 apparently healthy controls.

Results: There were highly significant statistical increases in RF, and anti-CCP antibodies in JIA patients as compared with their controls, while there was insignificant statistical difference between both groups regarding 14-3-3 protein eta. There were significant statistical increases in14-3-3 protein eta and anti-CCP antibodies in adult RA patients as compared with their controls. In JIA patients, there was significant increase in disease activity score 28 (DAS 28) among patients with +ve RF and +ve anti-CPP, meanwhile there were non-significant relation between DAS 28 and CRP results. Among cases with RA, there was non-significant relation between DAS 28 and the 3 markers (CRP, RF, and anti-CCP antibodies). At cutoff point of 0.19 $\mathrm{ng} / \mathrm{ml}$ (which was used in many previous studies as the best for 14-3-3 eta protein), our results showed sensitivity and specificity for this marker in JIA (15\% and 100\%) . In RA, we found $90 \%$ sensitivity and $90 \%$ specificity for this marker at the same cutoff point. Our study revealed that serum 14-3-3 eta protein level was significantly correlated to disease severity score 28 (DAS 28) for JIA ( $r=0.49 / \mathrm{P}=0.0288$ ), while for $\mathrm{RA}(\mathrm{r}=0.8502 / \mathrm{P}=0.0001)$.

Conclusion: anti-CCP antibodies were prevalent among polyarticular onset JIA patients compared to other subtypes of the disease. 14-3-3 protein had +ve correlation with disease severity in both groups and needs further evaluation on larger samples.

Key words: $14-3-3$ protein eta, anti-CCP , RA and JIA. 


\section{INTRODUCTION}

Rheumatoid arthritis (RA) is the most common chronic autoimmune arthritis characterized mainly by symmetrical small joints inflammation (Zeng and Tan, 2018). RA exists all over the world, with a global prevalence rate of about $0.5-1 \%$ (Scott and Stevenson 2017). RA is a multifactorial disease with variable presentations and severity (Hirata et al., 2015). RA could lead to irreversible joint destruction and disability. Early diagnosis of RA combined with an accurate prognostic assessment and appropriate treatment strategy can significantly improve a patient's prognosis (Vermeer et al., 2011). Many kinds of biomarkers coexisted in the serum of RA patients and linked to progression of the disease (Wunderlich et al., 2016). Rheumatoid factor (RF) and cyclic citrullinated peptide antibodies (anti-CCP) are major serological markers for RA diagnosis and classification (Zeng and Tan 2018). Low sensitivity of these markers in early diagnosis and follow up of the disease leads the attempts to find more sensitive biomarkers (Smolen et al., 2016). 14-33(eta) protein, is an intracellular chaperone (cellular adapter) protein belongs to a family of seven isoforms named as; (i) beta (ii) gamma (iii) epsilon (iv) eta (v) tau (vi) and zeta (vii) sigma (Maksymowych et al., 2014).

During the early stages of the RA, 143-3nprotein released to the extra cellular space and acts as an inducer of innate immune system (Aletaha et al., 2010). Many inflammatory mediators and pathways that involved in the pathogenesis and progression of RA have been unregulated through $14-3-3 \eta$ protein
(Maksymowych et al., 2014). So, this marker in addition to existing biomarkers, can augment the lab efficacy in the early identification and progression assessment of the RA (Zeng and Tan, 2018). On the other hand, the most prevalent rheumatic disease in childhood is juvenile idiopathic arthritis (JIA) with global prevalence ranges from 7-401 per 100,000 children (Patwardhan, 2019). JIA patients are classified into 7 subtypes, which comprise systemic JIA, oligoarthritis, polyarthritis (RF negative), polyarthritis (RF positive), psoriatic arthritis, enthesitis-related arthritis (ERA) and undifferentiated arthritis (Wu and Rabinovich, 2019). JIA is a multifactorial heterogeneous childhood arthritis, diagnosed and classified according to the clinical presentation within 6 months of disease onset (Lin et al., 2011). This clinical classification has limited prognostic value and do not consider biomarkers other than RF in the diagnosis (Wallace et al., 2014). So, this cloudy classification may restrict the chance for early aggressive therapy of JIA. At present, the prognostic assessment in JIA is anticipated by the race, sex, age of onset, and some other points, that have observed through experience. Many RA biomarkers are not studied well in pediatric patients (Esbjornsson et al., 2015).

The present work aimed to investigate the existence of 14-3-3 (eta) protein, antiCCP antibodies, and RF in JIA and RA patients, comparing that with healthy controls and correlated its levels with Disease Activity Score (DAS 28) (Smoline et al., 2016).

\section{PATIENTS AND METHODS}

Study Design: A case control study was accomplished in Rheumatology, Clinical 
pathology and Pediatrics Departments of Al-Hussein and AL-Zahra'a Hospitals, AlAzharUniversity, Cairo, Egypt. Subjects were studied over a period of 12 months from March 2018 to Feb. 2019. The study was ratified by the local Ethics Committee. Informed written consents have been obtained prior to enrolment in the study.

Study Population: A cohort of 20 consecutive pediatric patients $(\leq 16$ years) who met the International League of Associations for Rheumatology [ILAR] (Petty et al., 2004), criteria for JIA were enrolled in the study as a group I. while group II comprised 20 patients (> 16 years) with RA diagnosed according to the American College of Rheumatology and European League Against Rheumatism classification criteria for RA (Aletaha et al., 2010). As a control, 40 candidates were enrolled from age and sex matched, apparently healthy individual.

All studied individuals were subjected to a detailed history taking, comprehensive clinical examination, routine laboratory investigations, and biomarkers assay (including RF, ANTICCP, and 14-3-3 protein). None of our candidates was conflicted with other diagnosis (e.g. systemic lupus erythematosus, ankylosing spondylitis...etc.), or have other chronic illness (e.g. Diabetes mellitus, organ failure ...etc.), or have active infection at the time of lab assessment.

Disease Activity Score 28 (DAS28), in its simplified version, was used for assessment of disease severity in patients of group I and II. DAS28 merges data of the number of painful and swollen joints, with 28 joints being selected, as well as
ESR or CRP and patient's global assessment measured on a visual analog scale (VAS) from zero to $10 \mathrm{~cm}$. DAS28 score was calculated using a mathematical formula, and the activity of arthritis can be interpreted in categorical scale (Aleta et al., 2010).

\section{Laboratory investigations: Blood} samples were divided into two portions :

- One portion was collected into EDITA containing tube for CBC estimation using fully automated cell counter, and for ESR estimation by Westegren method.

- The other portion was put in a plan tube, left to clot, then centrifuged at $1600 \mathrm{rpm}$ for 20minutes, and serum was separated and used for estimation of:

1. Liver and kidney function tests were done on Cobus C 311auto-analyzer.

2. C-reactive protein (CRP) by using Biocientifica S.A kit (latex agglutination slidetest). The test based upon the immunological agglutination reaction between CRP as an antigen and the corresponding antibody coated on the surface of biological inert latex particles.

- Positive test: Agglutination was tested within 2 minutes, showing a CR level equal or higher than 8 $\mathrm{mg} / \mathrm{L}$.

3. Rheumatoid factor by using Biocientifica S.A kit (latex agglutination slide test). The test based upon the immunological reaction between $\mathrm{RF}$ in the serum and the corresponding human antibody IgG coated onto polystyrene latex particles. When the serum containing 
RF was mixed with the RF latex, a resulting agglutination was observed.

- Positive results were shown through the agglutination of latex particles. Distinct agglutination indicated a RF concentration $\geq$ to $20 \mathrm{IU} / \mathrm{ml}$ in the undiluted sample.

4. anti-CCP (cyclic citrullinated peptide) by using QUANTA Lite® CCP3 IgG ELISA Kit from Inova Diagnostics. The antigen used in the QUANTA Lite ${ }^{\circledR}$ CCP3 IgG ELISA test was a systemic, cyclic citrullinated peptide that was found to have high sensitivity and specificity in detecting antibody in patients with RA. The assay was evaluated spectrophotometrically by measuring and comparing the color intensity that developed in the patient wells with the color in the control wells.

5. Human 14-3-3eta protein by using eta (YWHAH) ELISA Kit from Glory Science Co., Ltd. This ELISA kit used Sandwich-ELISA as the method.

\section{Statistical Analysis:}

Data were coded and entered using the statistical package SPSS (Statistical Package for the Social Sciences) version 25. Data were summarized using mean, standard deviation, median, minimum and maximum in quantitative data and using frequency (count) and relative frequency (percentage) for categorical data. The comparison between more than two groups with quantitative data and parametric distribution were done by using One Way ANOVA followed by post hoc analysis using Tukey's test. For comparing categorical data, Chi square (x2) test was performed. Exact test was used instead when the expected frequency was less than 5. Correlations between quantitative variables were done using Pearson correlation coefficient to assess the best cut off point with its sensitivity, specificity, positive predictive value (PPV) and negative predictive value (NPV). The confidence interval was set to $95 \%$, and the accepted margin of error was set to $5 \%$. P> 0.5 was considered significant.

\section{RESULTS}

There was significant statistical difference between Group I that comprised 20JRA patients with the pediatric controls as regard the white blood cells count, red blood cells count, hemoglobin content, platelet count, erythrocyte sedimentation rate (ESR), urea level, ALT, AST and CRP. Also, there were significant statistical differences between them regarding $\mathrm{RF}$, and ANTI-CCP antibodies (Table 1). 
ASSESSMENT OF 14-3-3 PROTEIN ETA AND ANTI-CYCLIC...

Table (1):Characteristics of the juvenile idiopathic arthritis

\begin{tabular}{|c|c|c|c|c|c|c|}
\hline \multirow{2}{*}{\multicolumn{2}{|c|}{$\begin{array}{ll}\text { Parameters } & \text { Groups } \\
\end{array}$}} & \multicolumn{2}{|c|}{ Pediatric Control } & \multicolumn{2}{|c|}{ JIA } & \multirow[t]{2}{*}{$P$ value } \\
\hline & & Mean & SD & Mean & SD & \\
\hline \multicolumn{2}{|c|}{ AGE (year) } & 12.10 & 2.40 & 11.78 & 2.26 & 0.640 \\
\hline \multicolumn{2}{|c|}{ WBCs $\left(\times 10^{3} / \mathrm{mm}^{3}\right)$} & 3.91 & 0.35 & 6.98 & 0.91 & $<0.001$ \\
\hline \multicolumn{2}{|c|}{ RBCs (x10 $/$ microliter) } & 4.14 & 0.45 & 4.56 & 0.40 & 0.004 \\
\hline \multicolumn{2}{|c|}{ Hb (gm/dL) } & 12.84 & 0.68 & 9.93 & 1.04 & $<0.001$ \\
\hline \multicolumn{2}{|c|}{ Platelets $\left(\times 10^{3} / \mathrm{mm}^{3}\right)$} & 275.60 & 34.24 & 297.05 & 33.97 & 0.043 \\
\hline \multicolumn{2}{|c|}{ ESR (mm/hr) } & 11.00 & 2.88 & 43.20 & 25.60 & $<0.001$ \\
\hline \multicolumn{2}{|c|}{ UREA(mg/dL) } & 13.15 & 1.35 & 21.20 & 4.38 & $<0.001$ \\
\hline \multicolumn{2}{|c|}{ CREAT(mg/dL) } & 0.36 & 0.08 & 0.47 & 0.25 & 0.383 \\
\hline \multicolumn{2}{|c|}{ ALT(U/L) } & 9.20 & 1.32 & 14.25 & 2.77 & $<0.001$ \\
\hline \multicolumn{2}{|c|}{$\operatorname{AST}(\mathbf{U} / L)$} & 11.80 & 1.79 & 32.45 & 4.06 & $<0.001$ \\
\hline \multicolumn{2}{|c|}{ 14-3-3 eta protein $(\mathrm{ng} / \mathrm{ml})$} & 0.071 & 0.071 & 0.43 & 1.16 & 0.175 \\
\hline & & \multicolumn{2}{|c|}{ Pediatric Control } & \multicolumn{2}{|c|}{ JIA } & \multirow[t]{2}{*}{$P$ value } \\
\hline & & Count & $\%$ & Count & $\%$ & \\
\hline \multirow[t]{2}{*}{ SEX } & Male & 4 & 20.0 & 3 & 15.0 & \multirow[t]{2}{*}{1} \\
\hline & Female & 16 & 80.0 & 17 & 85.0 & \\
\hline \multirow[t]{2}{*}{ CRP } & Positive & 0 & 0.0 & 13 & 65.0 & \multirow{2}{*}{$<0.001$} \\
\hline & Negative & 20 & 100.0 & 7 & 35.0 & \\
\hline \multirow[t]{2}{*}{ RF } & Positive & 0 & 0.0 & 6 & 30.0 & \multirow[t]{2}{*}{0.020} \\
\hline & Negative & 20 & 100.0 & 14 & 70.0 & \\
\hline \multirow{2}{*}{$\begin{array}{c}\text { ANTI-CCP } \\
\text { ANTIBODIES }\end{array}$} & Positive & 0 & 0.0 & 6 & 30.0 & \multirow[t]{2}{*}{0.020} \\
\hline & Negative & 20 & 100.0 & 14 & 70.0 & \\
\hline
\end{tabular}

Group II that comprised 20 RA patients had significant statistical difference with the adult control group

regarding ESR, serum creatinine, ALT, CRP, RF, ANTI-CCP antibodies, and 14-3-3 eta protein (Table 2).

Table (2): Characteristics of the adult rheumatoid arthritis

\begin{tabular}{|c|c|c|c|c|c|c|}
\hline \multirow{2}{*}{\multicolumn{2}{|c|}{$\begin{array}{ll}\text { Parameters } & \text { Groups } \\
\end{array}$}} & \multicolumn{2}{|c|}{ Control } & \multicolumn{2}{|c|}{$\mathbf{R A}$} & \multirow[t]{2}{*}{$P$ value } \\
\hline & & Mean & SD & Mean & SD & \\
\hline \multicolumn{2}{|c|}{ AGE (year) } & 45.75 & 9.11 & 45.85 & 1181 & 0.779 \\
\hline \multicolumn{2}{|c|}{ WBCs $\left(\times 10^{3} / \mathrm{mm}^{3}\right)$} & 5.63 & 0.81 & 5.50 & 1.51 & 0.429 \\
\hline \multicolumn{2}{|c|}{ RBCs (x10 $/$ microliter) } & 4.27 & 0.49 & 4.40 & 0.46 & 0.512 \\
\hline \multicolumn{2}{|c|}{$\mathrm{Hb}(\mathrm{gm} / \mathrm{dL})$} & 10.82 & 1.10 & 11.19 & 1.31 & 0.414 \\
\hline \multicolumn{2}{|c|}{ Platlets $\left(x 10^{3} / \mathrm{mm}^{3}\right)$} & 255.40 & 58.28 & 254.20 & 80.07 & 0.698 \\
\hline \multicolumn{2}{|c|}{ ESR (mm/hr) } & 13.00 & 3.18 & 51.55 & 22.22 & $<0.001$ \\
\hline \multicolumn{2}{|c|}{ UREA(mg/dL) } & 28.55 & 4.75 & 31.85 & 11.07 & 0.529 \\
\hline \multicolumn{2}{|c|}{ CREAT(mg/dL) } & 0.76 & 0.14 & 0.61 & 0.12 & 0.004 \\
\hline \multicolumn{2}{|c|}{ ALT(U/L) } & 22.20 & 3.98 & 18.05 & 6.68 & 0.043 \\
\hline \multicolumn{2}{|c|}{$\operatorname{AST}(\mathbf{U} / \mathrm{L})$} & 21.95 & 4.01 & 22.75 & 11.67 & 0.429 \\
\hline \multicolumn{2}{|c|}{ 14-3-3 eta protein $(\mathrm{ng} / \mathrm{ml})$} & 0.101 & 0.061 & 4.48 & 5.32 & $<0.001$ \\
\hline & & \multicolumn{2}{|c|}{ Control } & \multicolumn{2}{|c|}{ RA } & \multirow[t]{2}{*}{ P value } \\
\hline & & Count & $\%$ & Coun & $\%$ & \\
\hline \multirow[t]{2}{*}{ SEX } & Male & 1 & 5.0 & 1 & 5.0 & \multirow[t]{2}{*}{1} \\
\hline & Female & 19 & 95.0 & 19 & 95.0 & \\
\hline \multirow[t]{2}{*}{ CRP } & Positive & 0 & 0.0 & 16 & 80.0 & \multirow[t]{2}{*}{$<0.001$} \\
\hline & Negative & 20 & 100.0 & 4 & 20.0 & \\
\hline \multirow[t]{2}{*}{ RF } & Positive & 0 & 0.0 & 17 & 85.0 & $<0.001$ \\
\hline & Negative & 20 & 100.0 & 3 & 15.0 & \\
\hline ANTI-CCP & Positive & 0 & 0.0 & 13 & 65.0 & $<0.001$ \\
\hline ANTIBODIES & Negative & 20 & 100.0 & 7 & 35.0 & \\
\hline
\end{tabular}


About comparison between group I and group II, there was significant statistical difference between both groups regarding the $\mathrm{RF}$, anti-CCP antibodies, and 14-3-3 eta protein results. While there was no significant statistical difference between them in disease activity scores 28 (DAS 28Table 3).

Table (3): Comparison between patients with JRA and those with RA

\begin{tabular}{|c|c|c|c|c|c|c|}
\hline \multirow{2}{*}{\multicolumn{2}{|c|}{$\begin{array}{ll}\text { Parameters } & \text { Groups } \\
\end{array}$}} & \multicolumn{2}{|c|}{ JRA } & \multicolumn{2}{|c|}{ RA } & \multirow{2}{*}{$P$ value } \\
\hline & & Count & $\%$ & Count & $\%$ & \\
\hline \multirow[t]{2}{*}{ SEX } & Male & 3 & 15.0 & 1 & 5.0 & \multirow{2}{*}{0.605} \\
\hline & Female & 17 & 85.0 & 19 & 95.0 & \\
\hline \multirow[t]{2}{*}{ CRP } & Positive & 13 & 65.0 & 16 & 80.0 & \multirow{2}{*}{0.288} \\
\hline & Negative & 7 & 35.0 & 4 & 20.0 & \\
\hline \multirow[t]{2}{*}{$\mathbf{R F}$} & Positive & 6 & 30.0 & 17 & 85.0 & \multirow{2}{*}{$<0.001$} \\
\hline & Negative & 14 & 70.0 & 3 & 15.0 & \\
\hline \multirow{2}{*}{$\begin{array}{c}\text { ANTI-CCP } \\
\text { ANTIBODIES }\end{array}$} & Positive & 6 & 30.0 & 13 & 65.0 & \multirow{2}{*}{0.027} \\
\hline & Negative & 14 & 70.0 & 7 & 35.0 & \\
\hline & & Mean & SD & Mean & SD & P value \\
\hline \multicolumn{2}{|c|}{ 14-3-3 eta protein $(\mathrm{ng} / \mathrm{ml})$} & 0.43 & 1.16 & 4.48 & 5.32 & 0.0020 \\
\hline \multicolumn{2}{|c|}{$\begin{array}{c}\text { Disease Activity Score } 28 \\
\text { (DAS28) }\end{array}$} & 4.45 & 0.9 & 4.02 & 0.75 & 0.109 \\
\hline
\end{tabular}

Of 20 JIA patients recruited for the study, 11 cases $(55 \%)$ were of polyarticular subtype ( 6 cases have $+v e$ results for both markers [RF and anti$\mathrm{CCP}]$, while 5 cases have negative markers), 7 cases (35\%) with oligoarthritis onset $(0 \mathrm{RF}+\mathrm{ve}$ and 0 anti-CCP antibodies +ve) and 2 cases with systemic onset JIA ( $0 \mathrm{RF}+\mathrm{ve}$ and 0 anti-CCP antibodies +ve). On the other hand, 12 cases of RA candidates in the have +ve results for both

markers $[\mathrm{RF}$ and ANTI-CCP
antibodies], 5 cases have +ve results for RF only, 1 case +ve for anti-CCP antibodies only, and 2 cases have -ve results for both markers. Elicited data showed statistically significant association between results of both markers in JIA group ( $\mathrm{P}$ value < 0.001), and non-significant association between them among cases of RA group (Table 4).

Table (4): Relation between RF and ANTI-CCP antibodies results among cases

\begin{tabular}{|c|c|c|c|c|c|c|c|}
\hline \multirow{2}{*}{ Groups } & R.F. & \multicolumn{2}{|c|}{ Positive } & \multicolumn{2}{|c|}{ Negative } & P value \\
\cline { 4 - 8 } & & Count & $\%$ & Count & \% & \\
\hline \multirow{2}{*}{$\begin{array}{c}\text { JIAcases } \\
\text { (GroupI) }\end{array}$} & \multirow{2}{*}{ ANTICCP } & Positive & 6 & 100.0 & 0 & 0.0 & $<0.001$ \\
\cline { 3 - 7 } & & Negative & 0 & 0.0 & 14 & 100.0 & \\
\hline $\begin{array}{c}\text { RA cases } \\
\text { (GroupII) }\end{array}$ & ANTICCP & Positive & 12 & 70.6 & 1 & 33.3 & 0.270 \\
\cline { 3 - 7 } & Negative & 5 & 29.4 & 2 & 66.7 & \\
\hline
\end{tabular}

Tables (5 \& 6) illustrated the relation between disease activity score 28 (DAS 28) and results of 3 biochemical markers (CRP, RF, and ANTI-CCP antibodies) in both groups. Regarding cases of group I, there was significant increase in disease activity score 28 (DAS 28) among patients with +ve RF and +ve ANTI-CPP, while there was non-significant relation between DAS 28 and CRP results. On the other hand, cases of group II, there was non-significant relation between DAS 28 and the 3 markers (CRP, RF, and ANTI-CCP antibodies). 
ASSESSMENT OF 14-3-3 PROTEIN ETA AND ANTI-CYCLIC...

Table (5): Relation between DAS28 and (CRP, RF, and anti-CCP antibodies) in JIA cases

\begin{tabular}{|c|c|c|c|c|c|c|c|c|c|c|c|}
\hline \multicolumn{6}{|c|}{ Positive } & \multicolumn{5}{|c|}{ Negative } & p-value \\
\hline$\overline{\mathrm{CRP}}$ & Mean & SD & Med. & Min. & Max. & Mean & SD & Med. & Min. & Max. & \\
\hline 28 & 4.48 & 0.86 & 4.20 & 3.70 & 6.00 & 4.37 & 1.02 & 4.50 & 3.20 & 5.80 & 0.757 \\
\hline & Mean & SD & Med. & Min. & Max. & Mean & SD & Med. & Min. & Max. & \\
\hline 28 & 5.60 & 0.58 & 5.85 & 4.50 & 6.00 & 3.95 & 0.41 & 3.95 & 3.20 & 4.70 & $<0.001$ \\
\hline Anti- & Mean & SD & Med. & Min. & Max. & Mean & SD & Med. & Min. & Max. & \\
\hline $\begin{array}{l}\text { DAS } \\
28\end{array}$ & 5.60 & 0.58 & 5.85 & 4.50 & 6.00 & 3.95 & 0.41 & 3.95 & 3.20 & 4.70 & $<0.001$ \\
\hline
\end{tabular}

Table (6): Relation between DAS28 and [CRP, RF and anti-CCP antibodies] in RA cases

\begin{tabular}{|c|c|c|c|c|c|c|c|c|c|c|c|}
\hline \multicolumn{6}{|c|}{ Positive } & \multicolumn{5}{|c|}{ Negative } & \multirow[t]{2}{*}{ p-value } \\
\hline CRP & Mean & SD & Med. & Min. & Max. & Mean & SD & Med. & Min. & Max. & \\
\hline & 4.19 & 0.67 & 4.15 & 3.20 & 6.00 & 3.38 & 0.79 & 3.15 & 2.70 & 4.50 & 0.099 \\
\hline & & & & & & & & & & & \\
\hline R F & Mean & SD & Med. & Min. & Max. & Mean & SD & Med. & Min. & Max. & \\
\hline & 4.07 & 0.74 & 3.90 & 3.00 & 6.00 & 3.77 & 0.95 & 4.10 & 2.70 & 4.50 & 0.842 \\
\hline & & & & & & & & & & & \\
\hline Anti- & Mean & SD & Med. & Min. & Max. & Mean & SD & Med. & Min. & Max. & \\
\hline CCP & 4.18 & 0.81 & 4.20 & 3.00 & 6.00 & 3.73 & 0.57 & 3.90 & 2.70 & 4.30 & 0.275 \\
\hline & & & & & & & & & & & \\
\hline
\end{tabular}

At cut-off point $0.11 \mathrm{ng} / \mathrm{ml}$, serum 14-3-3 eta proteinhad $80 \%$ sensitivity and $80 \%$ specificity among patients of group I and their controls for prediction of JIA, while had $90 \%$ sensitivity and $95 \%$ specificity at cut- off point $0.25 \mathrm{ng} / \mathrm{ml}$ among adult patients of group II and their controls for RA prediction. Sensitivity and Specificity of 14-3-3 eta protein at variable cutoff pointed for diagnosis of JIA and RA (Table 7).

Table (7): Sensitivity and specificity of 14-3-3 eta protein at variable cutoff points for diagnosis of JIA and RA

\begin{tabular}{|c|c|c|c|c|c|}
\hline \multicolumn{3}{|c|}{ JIA } & \multicolumn{3}{c|}{ RA } \\
\hline $\begin{array}{c}\text { Cut point } \\
(\mathrm{ng} / \mathrm{ml})\end{array}$ & Sensitivity & Specificity & $\begin{array}{c}\text { Cut point } \\
(\mathrm{ng} / \mathrm{ml})\end{array}$ & Sensitivity & Specificity \\
\hline 0.11 & $80 \%$ & $80 \%$ & 0.19 & $90 \%$ & $90 \%$ \\
\hline 0.17 & $50 \%$ & $100 \%$ & 0.25 & $90 \%$ & $95 \%$ \\
\hline 0.19 & $15 \%$ & $100 \%$ & 0.32 & $85 \%$ & $100 \%$ \\
\hline
\end{tabular}

Pearson correlation analysis showed that the serum level of 14-3-3 eta protein had significant +ve correlation with the disease activity score 28 (DAS 28) among patients of JIA and RA (figure 1). 

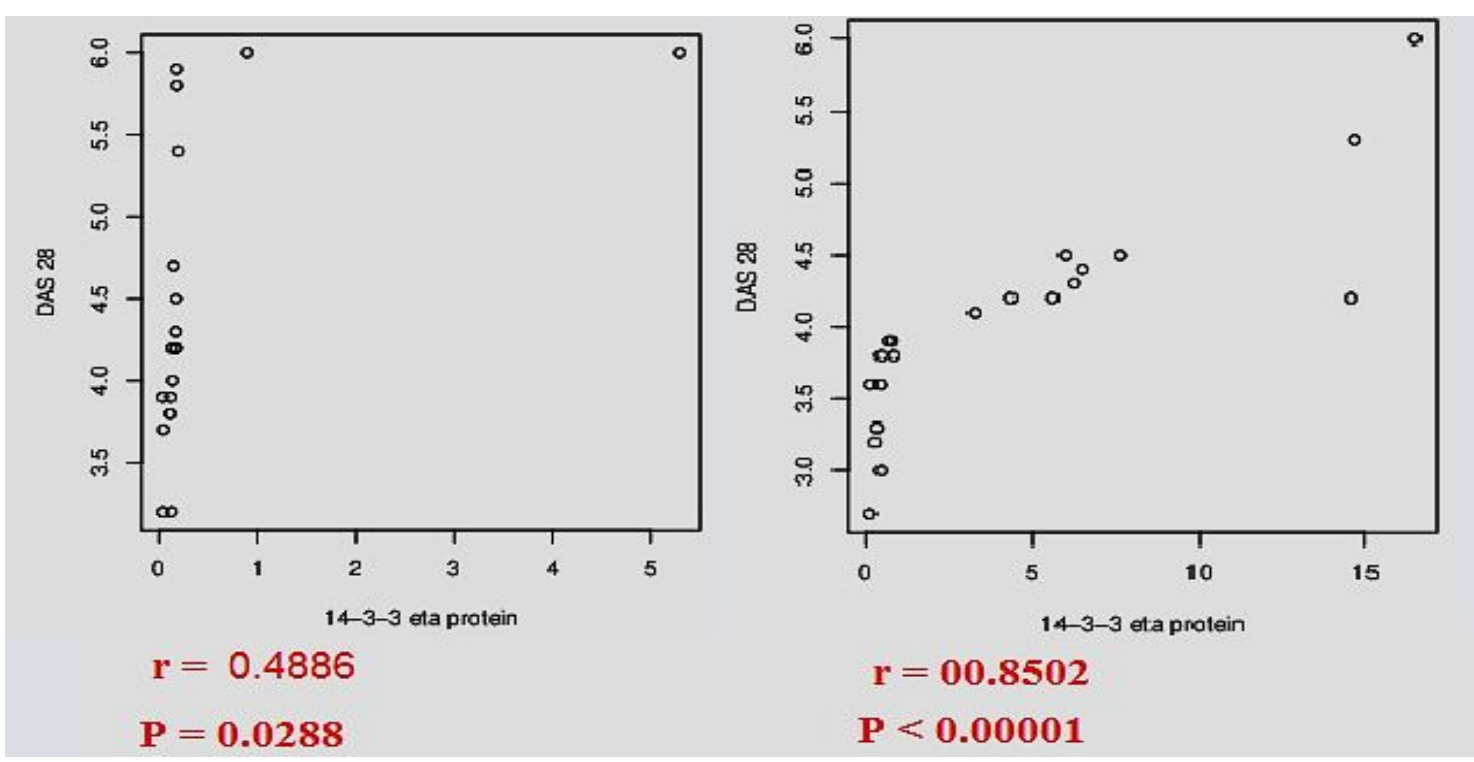

Figure (1): scatter plot curve of (DAS 28) vs 14-3-3 eta protein level among candidates of group I (left) and group II (right) showing Pearson Correlation Coefficient (r) and P value.

\section{DISCUSSION}

This study was formulated to determine the existence of 14-3-3 eta protein, anti-CCP antibodies, and RF in 2 groups of patients: Group I included JIA patients, and group II included RA patients. The current study linked these markers level to the disease activity score 28 (DAS 28). In the current study, 20 JIA patients were sequentially enrolled. RF and ant-CCP antibodies were positive in 6 $(30 \%)$ cases as all of them having polyarticular onset. Other cases (70\%) and their controls had -ve results for both markers. On the same line, Omar et al. (2013) studied a cohort of 54 JIA patients and reported that $25.9 \%$ have +ve RF and $24.1 \%$ have +ve ANTI-CCP antibodies of polyarticular subtype.

Habib et al. (2008) stated that ANTICCP antibodies had been detected in $20.6 \%$ of cases with JIA. All ANTI-CCP antibodies +ve candidates were of the polyarticular RF +ve subtype.
The predominance of ANTI-CCP antibodies in RF + ve polyarticular subtype could be explained by the immunologic theory of this subtype. So, it may be considered that the juvenile equivalent of RA (Gupta et al. 2010). Polyarticular RF +ve JIA patients had much more probability to have ANTI-CCP antibodies +ve results (Omar et al., 2013). These results were comparable to our findings. The previous data clearly demonstrate wide differences regarding the existence of anti-CCP antibodies among different countries and races (Thierry et al., 2014).

Furthermore, our results suggesting that anti-CCP antibodies assay may not be better than RF in typing of polyarticular JIA. However, the absence of anti-CCP antibodies, in other subtypes of JIA and in all healthy controls, suggested a possible valuable role for anti-CCP antibodies test in affirming the diagnosis of polyarticular subtype and in exclusion of non-JIA polyarthritis in children (Omar et al ., 2013). 
Our results showed that out of 20 adult RA patients, there were $60 \%$ of cases have +ve results for both markers. $100 \%$ of the adult controls were -ve for both markers. These results were parallel to the results of Habib et al. (2008) who found that anti-CCP antibodies positivity had been found in $2 / 3$ to $3 / 4$ of RA patients (mostly in $\mathrm{RF}+$ ve cases).

However, anti-CCP antibodies positivity, in our JIA patients, was still less than the adult patients with RA $(30 \%$ versus $65 \%$ ). This could be referred to the heterogeneous nature of JIA subtypes when compared to RA .

Moreover, our results showed statistically significant association between both markers in JIA patients and non-significant association between them among RA cases. Analogous results had been reported by multiple previous studies (Omar et al., 2013).

In our JIA patients, there were significant increases in disease activity score 28 (DAS 28) among patients with +ve RF and +ve anti-CPP. Meanwhile, there was non-significant relation between DAS 28 and CRP results. Among cases with RA, there were non-significant relations between DAS 28 and the 3 markers (CRP, RF, and anti-CCP antibodies).

Many studies reported a possible link between anti-CCP antibodies and disease severity in JIA and RA (Patwardahan, 2019). Gupta et al. (2010) reported that ANTI-CCP antibodies had been detected significantly more among JIA patients with serious disease manifestations.

Regarding RA, our results were compatible with $\mathrm{V}$ anichapuntu et al.,
(2010) and Safi \& Houssien (2018) were their results elicited limited role of antiCCP antibodies in predicting disease activity among patients with RA.

In the current study, serum14-3-3 eta protein was found significantly higher in group II when compared to their control group or when compared to group I patients. In group I, there was no significant statistical difference between JIA patients and their controls regarding the level of serum 14-3-3 eta protein.

At cutoff point of $0.19 \mathrm{ng} / \mathrm{ml}$, which was used in many previous studies as the best for 14-3-3 eta protein (Maksymowch et al., 2014), our results showed (sensitivity and specificity) for this marker in JIA (15\% and $100 \%)$ respectively. In RA there were $90 \%$ sensitivity and $90 \%$ specificity for these markers at the same cutoff point.

Carrier et al. (2016) showed that both among the early and established RA candidates, 14-3-3 eta was higher in patients' serum even those RF -ve and/or anti-CCP-ve. So, addition of 14-3-3 eta to anti-CCP and/or RF would raise the diagnostic efficacy.

Maksymowych et al. (2014) evaluated the diagnostic efficacy of 14-3-3 eta in 619 candidates comprising early established RA patients and controls. They concluded that median were significantly higher in those with early and established RA when compared with healthy individuals. Regarding comparison between established RA and healthy controls, their results demonstrated that at a cutoff value of 143-3 eta protein $\geq 0.19 \mathrm{ng} / \mathrm{mg}$, displayed a sensitivity of $77.0 \%$ and a specificity of $92.6 \%$. At the same cutoff value, the 
results displayed a sensitivity of $63.6 \%$ and a specificity of $92.6 \%$, when comparing early RA with healthy controls. Comparable results had been elicited by Gong et al. (2017).

Our study revealed that serum 14-3-3 eta protein level was significantly correlated to disease severity score 28 (DAS 28).

Maksymowych et al. (2014) reported that higher median baseline Disease Activity Score and health assessment questionnaire measures were found in 143-3 eta +ve candidates with RA compared to the 14-3-3 eta -ve patients with RA.

Analysis of results from other studies confirmed thelink between RA severity and 14-3-3 eta protein. Hirata et al. (2015) stated that the usefulness of 14-3-3 eta in assessment of disease severity and treatment response was investigated in established RA candidates before treatment initiation and 1 year after. Parameters associated to disease severity such as ESR,CRP, RF, Clinical Disease Activity Index, Simple Disease Activity Index, 28-joint tender joint count, 28-joint swollen joint count, Sharp/van der Heijde $(\mathrm{SvH})$ score DAS 28, joint space narrowing, erosion score, and ANTI-CCP were included as assessment parameters. Results showed that 14-3-3 eta +ve patients had higher median (IQR) DAS28, ESR, Clinical Disease Activity Index, Simple Disease Activity Index, 28-joint tender joint count, 28-joint swollen joint count scores and elevated ESR, ANTI$\mathrm{CCP}, \mathrm{RF}$ before treatment initiation.

Gong et al. (2017) found that +ve correlation between 14-3-3 eta protein with visual analog scales and health assessment questionnaire, which assessed joints function, and negative correlation was elicited between 14-3-3 eta protein and bone mineral density. No studies investigated14-3-3 eta protein in JIA patients, so we cannot compare our results with the others.

\section{CONCLUSION}

Anti-CCP antibodies were prevalent among polyarticular onset JIA patients compared to other subtypes of the disease and highly linked to RF. Also, our study approved that 14-3-3 eta protein has a role in detection of rheumatoid arthritis along with other biomarkers in RA and JIA. The new marker, 14-3-3 eta protein, also showed positive correlation with disease activity in both groups and there is a need for further evaluation on larger sample of Egyptian population.

\section{CONFLICT OF INTEREST}

The authors declare no conflict of interest.

\section{REFERENCES}

1. Aletaha D, NeogiT,Silman AJ, Naden RL, Felson DT and Aggarwal R (2010): Rheumatoid arthritis classification criteria: an American College of Rheumatology/European League Against Rheumatism collaborative initiative. Arthritis Rheum, 62:2569-81.

2. Carrier N, Marotta $A$ and de BrumFernandes AJ (2016): Serum levels of 14-3$3 \eta$ protein supplement $\mathrm{C}$-reactive protein and rheumatoid arthritis-associated antibodies to predict clinical and radiographic outcomes in a prospective cohort of patients with recent-onset inflammatory polyarthritis. Arthritis Res. Ther. 18(1), 37-50.

3. Esbjornsson AC, Aalto $\mathrm{K}$ and Brostrom EW (2015): Ankle arthritis predicts polyarticular disease course and unfavourable outcome in children with juvenile idiopathic arthritis. Clin. Exp. Rheumatol., 33:751-757.

4. Gong X, Xu S and Wu Y (2017): Elevated serum 14-3-3 $\eta$ protein may be helpful for 
diagnosis of early rheumatoid arthritis associated with secondary osteoporosis in Chinese population. Clin. Rheumatol., 36:(11): 2581-2587.

5. Gupta R, Thabah MM and Vaidya B (2010): Anti-cyclic citrullinated peptide antibodiesin juvenile idiopathic arthritis. Indian J Pediatr, 77:41-4.

6. Habib HM, Mosaad YM and Youssef HM (2008): Anti-cyclic citrullinated peptide antibodies in patients with juvenile idiopathic arthritis. Immunol. Invest., 37(8):849-57.

7. Hirata S, Marotta A, Gui Y, Hanami K and Tanaka Y (2015): Serum 14-3-3 $\eta$ level is associated with severity and clinical outcomes of rheumatoid arthritis, and its pretreatment level is predictive of DAS28 remission with tocilizumab.Arthritis Res Ther., 9;17:280-287.

8. Lin YT, Wang CT, Gershwin ME and Chiang BL (2011): The pathogenesis of oligoarticular/polyarticular versus systemic juvenile idiopathic arthritis. Autoimmun Rev. 10: 482-489.

9. Maksymowych WP, Van Der Heijde D, Allaart CF, Landewé R, Boire $G$ and Tak PP (2014): 14-3-3eta is a novel mediator associated with the pathogenesis of rheumatoid arthritis and joint damage. Arthritis Res. Ther. 16:R99-108.

10. Omar A, Abo-Elyoun I, Hussein H, Nabih M, Atwa H, Gad S and Emad Y (2013): Anti-cyclic citrullinated peptide (antiCCP)antibody in juvenile idiopathic arthritis (JIA): correlations with disease activity and severity of joint damage (amulticenter trial). Joint Bone Spine, 80:38-43.

11. Patwardhan A (2019): The Utility and Experience with Disease Biomarkers in Juvenile Onset Arthritis vs. Adult Onset Arthritis Cureus , 13;11(7):e5131-42.

12. Petty RE, Southwood TR, Manner $P$ and Glass D (2004) : International League of associations of Rheuomatology Classification of Juvenile Idiopathic arthritis. .Clinc. Exp. Rhuomatol., 31:390-392.

13. Safi MA and Houssien DT (2018): Anticyclic citrullinated peptide and rheumatoid factor (prevalence and association) in Saudi rheumatoid arthritis patients. JKAU Med Sci., 25 (2): 1-10.

14. Scott DL and Stevenson MD (2017): Treating active rheumatoid arthritis with Janus kinase inhibitors. Lancet, 390 (10093): 431-432.

15. Smolen JS, Aletaha D and Mcinnes IB (2016): Rheumatoid arthritis. Lancet, 388 : 2023-2038.

16. Thierry S, Fautrel B, Lemelle I and GuilleminM (2014): Prevalence and incidence of juvenile idiopathic arthritis: a systematic review. Joint Bone Spine, 81:112-117.

17. Vanichapuntu M, Phuekfon P, Suwannalai $P$, VerasertniyomO, Nantiruj $K$ and Janwityanujit S (2010): Are anticitrullineauto antibodies better serum markers for rheumatoid arthritis than rheumatoid factor in Thai population. Rheumatol. Int., 30(6): 755-759.

18. Vermeer M, Kuper HH, Hoekstra M, Haagsma CJ, Posthumus MD, Brus HL, van Riel PL and van de Laar MA (2011): Implementation of a treat-to-target strategy in very early rheumatoid arthritis: results of the Dutch rheumatoid arthritis monitoring remission induction cohort study. Arthritis Rheum. 63: 2865-2872.

19. Wallace CA, Ringold $S$ and Bohnsack J (2014): Extension study of participants from the trial of early aggressive therapy injuvenile idiopathic arthritis. J Rheumatol. , 41:24592465.

20. Wu EY and Rabinovich CE (2019): Juvenile Idiopathic Arthritis. In: Kliegman RM, St Geme JW, Blum NJ, Shah SS, Tasker RC, Wilson KM, Behrman RE, editors. Nelson Textbook of Pediatrics. 21th ed. Pbi. PA: Elsevier Inc. Chapter 180:1831-1839.

21. Wunderlich C, Oliviera I, Figueiredo CP, Rech J and Schett $G$ (2016): Effects of DMARDs on citrullinated peptide autoantibody levels in RApatients - a longitudinal analysis. Semin. Arthritis Rheum., 46(6): 709-714.

22. Zeng T and Tan L (2018): $14-3-3 \eta$ protein: a promising biomarker for rheumatoid arthritis. Biomark Med. ,12(8): 917-925. 





المصابين بالتهاب المفاصل الروماتيدي

محمد عبد المليك حسن - رشا محمود جودة-وجنات عفت السياء* - إيمان أحمد قاسم** أقسام طب الأطفال و الباطنة العامة* و البالثولوجيا الإكلينيكية*** ـ كلية الطب- جامعةالأزهر

خلفيــة البحــث : يعـــــــروتين 14-3-3-إيتـــا بــروتين خلــوي مــنظم يخــرج إلــي الأمــاكن

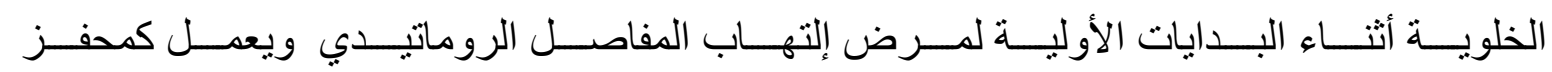

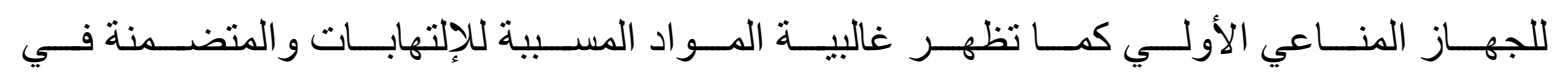



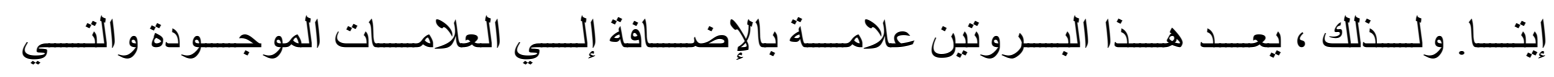

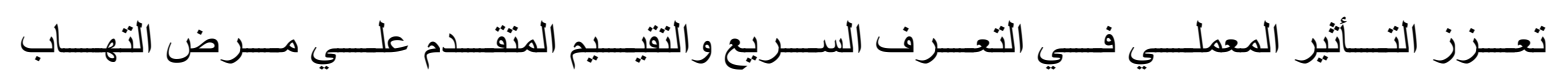
المفاصل الروماتيدي.

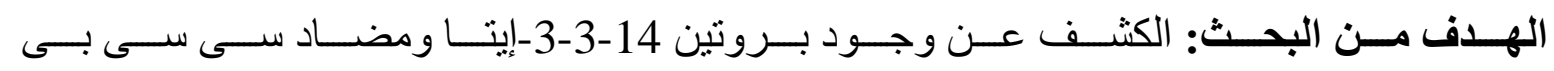
فى الأطفال المصابين بإلتهاب المفاصل.

الأولـــى و الكبـــار المصـــابين بالتهـــاب المفاصـــل الروماتيـــــي مقارنـــة بالأصــــــاء كمجمو عة ضابطة و علاقتهما بالنشاط المرضي.

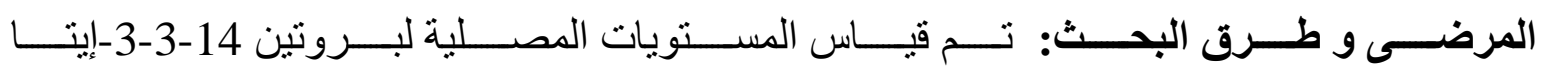

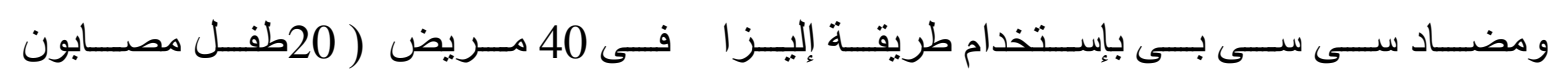

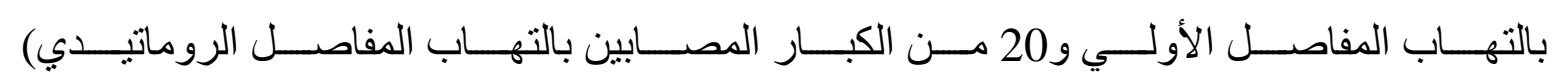
علاوة على 40 شخص من الأصحاء كمجمو عة ضابطة.

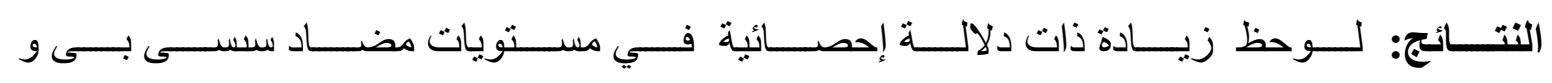
عامل روماتويد فى الأطفال المصابين بإلتهاب.

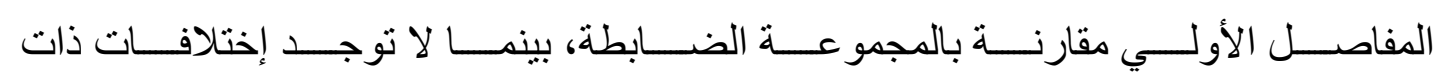

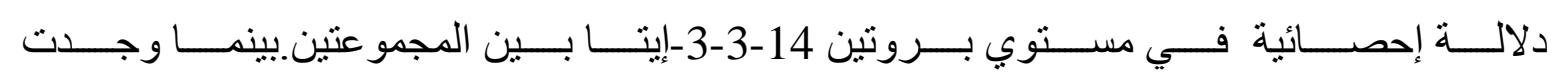




\section{ASSESSMENT OF 14-3-3 PROTEIN ETA AND ANTI-CYCLIC...}

زيـــادة ذات دلالــة احصــائية فــي مســتويات بـروتين 14-3-3-إيتـــا ومضــاد ســى سـى بــى فى الكبار المصابين.

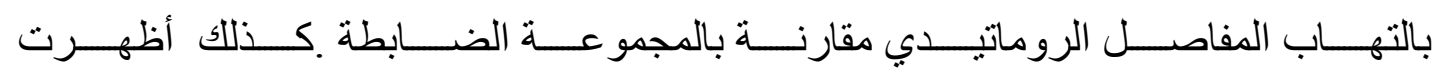

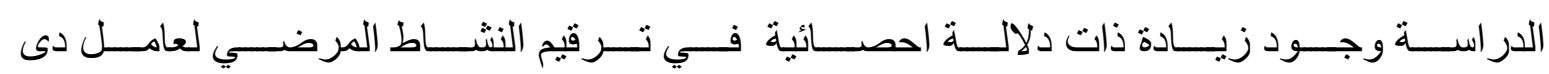

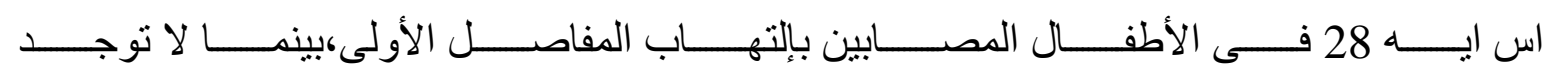

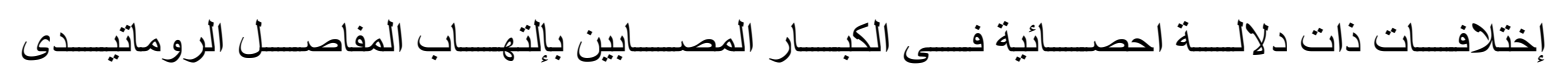
و الخاصة بترقيم النشاط المرضى دى اس ايه 28.

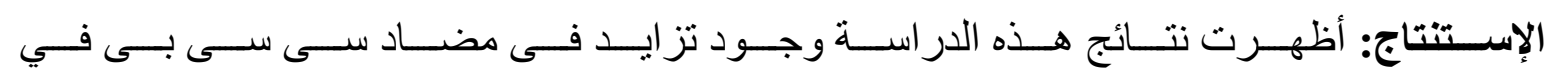

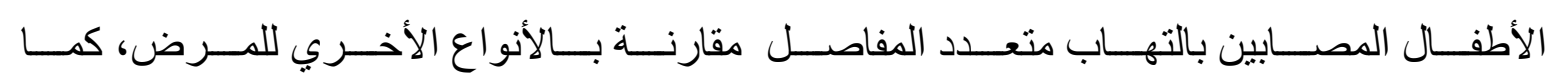


المجمو عتين، مع الإحتياج إلي تقييمات أخري علي عينات أكبر. 